\title{
Pengaruh produk domestik regional bruto dan inflasi terhadap dana pihak ketiga serta penyaluran kredit
}

\author{
Aspyan Noor ${ }^{1}$, Anis Rachma Utary ${ }^{2}$, Fitriadi ${ }^{3}$ \\ Fakultas Ekonomi dan Bisnis Universitas Mulawarman Samarinda, Indonesia \\ ${ }^{1}$ Email: aspyan.noor@feb.unmul.ac.id \\ ${ }^{2}$ Email: anis.rachma.utary@feb.unmul.ac.id \\ ${ }^{3}$ Email: fitriadi@feb.unmul.ac.id
}

\begin{abstract}
Abstrak
Penelitian kuantitatif deskriptif ini bertujuan untuk menganalisis pengaruh Produk Domestik Regional Bruto (X1) dan Inflasi (X2) terhadap Dana Pihak Ketiga (Y1) dan penyaluran Kredit (Y2) pada Bankaltim di Propinsi Kalimantan Timur. Data deret waktu untuk penelitian ini adalah: Produk Domestik Regional Bruto dan Inflasi yang diperoleh dari data Biro Statistik, dan Dana Pihak Ketiga dan Distribusi Kredit yang diberikan oleh Bankaltim, mulai dari tahun 2006 sampai 2013. Data tersebut kemudian dianalisis dengan cara Analisis Jalur dengan bantuan Perangkat Lunak SPSS. Hasil penelitian menunjukkan bahwa Produk Domestik Regional Bruto dan Inflasi berpengaruh positif langsung terhadap variabel Dana Pihak Ketiga, dan Variabel Distribusi Kredit. Pengaruh tidak langsung Produk Domestik Bruto dan Inflasi terhadap Penyaluran Kredit juga positif namun tidak signifikan. Dan akhirnya, Dana Pihak Ketiga menunjukkan efek langsung positif yang tidak signifikan terhadap Penyaluran Kredit di Bankaltim.
\end{abstract}

Kata Kunci: produk domestik bruto; inflasi; dana pihak ketiga; distribusi kredit

\section{The effect of bruto regional domestic products and inflation to third party funds and distribution of bankaltim credit in kalimantan timur}

\begin{abstract}
This descriptive quantitative study aims to analyze the effect of Gross Regional Domestic Product (X1) and Inflation (X2) towards Third Parties Fund (Y1) and Credit distribution (Y2) at Bankaltim in East Kalimantan province. The time series data for this study are: Gross Regional Domestic Product and Inflation which were procured from Bureau of Statistics, and Third Parties Fund and Credit Distribution data which were provided by Bankaltim, ranging from 2006 until 2013. Those data were then analyzed by means of Path Analysis with the aid of SPSS Software. The result shows that Gross Regional Domestic Product and Inflation has positive direct effect towards Third Parties Fund variable, and Credit Distribution variable. The indirect effect of Gross Domestic Product and Inflation towards Credit Distribution also positive but not significant. And finally, Third Parties Fund shows positive insignificant direct effect towards Credit Distribution at Bankaltim.
\end{abstract}

Keywords: gross domestic product; inflation; third parties fund; credit distribution 


\section{PENDAHULUAN}

Di bulan Juli 2013, Kaltim mengalami inflasi sebesar 3,79 persen. Angka itu merupakan yang tertinggi pada tahun 2013. Dampak paling besar dari kenaikan harga BBM terlihat di kelompok kebutuhan transportasi yang mengalami inflasi tahunan hingga 21,31 persen. Disusul kelompok bahan makanan dan makanan jadi mengalami inflasi 11,74 persen dan 14,44 persen. Kelompok lain yang mengalami inflasi tertinggi adalah sub kelompok biaya tempat tinggal dengan 10,76 persen. Tarif dasar listrik yang sepanjang tahun 2013 beberapa kali mengalami kenaikan turut menjadi penyebab. Jika diurutkan berdasarkan daerah, Samarinda mengalami inflasi tertinggi di Kaltim sepanjang tahun 2013 yakni 10,37 persen. Dua kota yang lain yakni Balikpapan dan Tarakan mengalami inflasi 8,56 persen dan 10,35 persen. Lonjakan inflasi tahun 2013 tak lepas dari tindakan pemerintah yang kerap menunda kebijakan moneter. Sejak mencapai 13,06 persen pada tahun 2008, inflasi tahun 2013 merupakan yang tertinggi dalam lima tahun terakhir. Sebelumnya, Bank Indonesia menargetkan inflasi di Kaltim hanya 5,5 persen hingga 6,0 persen sepanjang tahun 2013. Masih tingginya angka inflasi nasional sepanjang 2013 menjadi salah satu sebab Bank Indonesia agak menahan laju kredit perbankan. Seperti diketahui, inflasi nasional per April tahun 2014 mencapai 7,25\%, sementara Kaltim 8,29\%. Sebelumnya, Bank Indonesia menargetkan pertumbuhan kredit perbankan tahun 2013 akan berada pada angka 15-17 persen. Kebijakan Bank Indonesia tersebut pada akhirnya juga turut berdampak pada target ekspansi kredit perbankan yang tidak seagresif tahun-tahun sebelumnya, termasuk target pertumbuhan kredit di sektor properti. Selain itu, kebijakan Bank Indonesia terkait Loan to Value (LTV) kredit pembiayaan properti akhir tahun 2012 mulai menunjukkan pengaruhnya. Beberapa perbankan yang sebelumnya cukup ekspansif dalam penyaluran KPR kini tak bisa seagresif dua tahun silam. Kebijakan BI terkait LTV merupakan salah satu langkah yang dilakukan untuk meredam lonjakan permintaan rumah yang bersifat spekulasi.

Dana Pihak Ketiga merupakan sumber dana terbesar yang dimiliki bank, karena dengan menghimpun DPK ini bank dapat menyalurkan kreditnya. Jadi besar kecilnya kredit yang disalurkan oleh bank bergantung pada keberhasilan bank dalam menghimpun DPK. Pada Juni tahun 2013, DPK Bankaltim sempat menyentuh Rp 34 triliun. Memasuki awal tahun 2014, angka tersebut justru menyusut menjadi Rp 19 triliun. Penyebabnya, pertumbuhan kredit Bankaltim yang tinggi. Bahkan, LDR Bankaltim mencapai 106 persen karena aliran kredit melampaui DPK. Faktor lain adalah belum masuknya dana perimbangan ke pemprov yang merupakan salah satu pemilik saham BPD Kaltim.

Bank Pembangunan Daerah Kaltim atau Bankaltim, menargetkan pertumbuhan kredit tahun 2014 bisa mencapai 22 persen. Namun, seiring dengan kebijakan pemerintah yang memperketat pertumbuhan kredit 15-17 persen terkait kondisi perekonomian yang belum sepenuhnya pulih, target pertumbuhan bank milik Pemerintah Provinsi Kaltim ini kemungkinan besar juga akan turut direvisi. Sepanjang tahun 2013, Bankaltim menunjukkan tren pertumbuhan penyaluran kredit yang cukup signifikan dari Rp 14,4 triliun pada tahun 2012 menjadi Rp 19 triliun. Bankaltim juga tengah berupaya untuk meningkatkan pendapatan dari layanan fee based income, dimana, untuk tahun pertama Bankaltim menargetkan kontribusi pendapatan sebesar Rp 10 miliar - Rp 15 miliar. Tahun ini, Bankaltim akan menyinergikan penyaluran kredit dengan program-program pembangunan yang sudah dicanangkan oleh Pemerintah Provinsi Kalimantan Timur, khususnya di sektor konstruksi dan pertanian, peternakan serta perikanan.

Berdasarkan penjelasan di atas, variabel PDRB dan Inflasi selain memengaruhi Pertumbuhan Kredit juga memengaruhi Dana Pihak Ketiga pada Bank karena PDRB dan Inflasi di suatu daerah berkaitan langsung dengan pendapatan masyarakat di daerah tersebut. Seperti penelitian yang dilakukan oleh Affandy (2011) yang menyatakan PDRB riil berpengaruh positif dan signifikan terhadap tabungan masyarakat, pendapat ini didukung oleh penelitian yang dilakukan oleh Sultana and Anwar (2010), Anthony (2012) dan Hendra (2012). Selain itu penelitian yang dilakukan oleh Chaturvedi et al. (2009) menyatakan bahwa adanya hubungan yang negatif antara tabungan nasional dan tingkat inflasi, berbeda dengan penelitian yang dilakukan oleh Hendra (2012) yang menyatakan bahwa tingkat inflasi mempunyai pengaruh positif terhadap jumlah simpanan masyarakat (DPK). 


\section{Kajian Pustaka}

Menurut Hossain (2010:142), dalam kepustakaan ilmu moneter, inflasi sudah memiliki makna yang pasti. Pada dasarnya yang disebut inflasi adalah berbagai kondisi dari kenaikan terus-menerus atas tingkat harga secara keseluruhan. Inflasi dalam definisinya yang demikianlah tidak sama dengan fluktuasi sesaat jangka pendek dari tingkat harga umum. Inflasi merupakan keadaan perekonomian yang ditandai oleh kenaikan harga secara cepat sehingga berdampak pada menurunnya daya beli, sering pula diikuti menurunnya tingkat tabungan dan atau investasi karena meningkatnya konsumsi masyarakat dan hanya sedikit untuk tabungan jangka panjang (Bank Indonesia, 2014). Miskhin (2008:13) mengemukakan bahwa inflasi adalah kenaikan tingkat harga yang terjadi terus-menerus, mempengaruhi individu, pengusaha, dan pemerintah. Inflasi secara umum dianggap sebagai masalah penting yang harus diselesaikan dan sering menjadi agenda utama politik dan pengambil kebijakan. Sukirno (2006:14) mengemukakan bahwa inflasi merupakan suatu proses kenaikan harga-harga yang berlaku dalam suatu perekonomian. Tingkat inflasi (persentase pertambahan kenaikan harga) berbeda dari satu periode ke periode lainnya, dan berbeda pula dari satu negara ke negara lainnya. Tingkat inflasi rendah, yaitu mencapai di bawah 2 atau 3 persen. Tingkat inflasi yang moderat mencapai di antara 4-10 persen. Inflasi yang sangat serius dapat mencapai tingkat beberapa puluh atau beberapa ratus persen dalam setahun. Berdasarkan pengertian-pengertian tersebut dapat disimpulkan bahwa inflasi merupakan suatu kondisi dimana terjadinya kenaikan harga-harga yang terjadi secara terus-menerus yang ditandai dengan menurunnya daya beli masyarakat sehingga berdampak kepada perekonomian suatu negara.

Setiap bank dalam menjalankan kegiatannya tentu membutuhkan dana. Pentingnya dana membuat bank harus mencari sumber-sumber dana dalam rangka membiayai kegiatan operasinya. Sumber dana tersebut salah satunya diperoleh dari Dana Pihak Ketiga, atau yang disebut dengan DPK. Dana Pihak Ketiga (DPK) merupakan simpanan pihak ketiga bukan bank yang terdiri dari Giro, tabungan dan Simpanan Berjangka (Bank Indonesia, 2014). Besarnya Dana Pihak Ketiga (DPK) sangat mempengaruhi keberhasilan suatu bank. Kasmir (2011:64) menyatakan, Dana Pihak Ketiga (DPK) merupakan sumber dana terpenting bagi kegiatan operasi suatu bank dan merupakan ukuran keberhasilan bank jika mampu membiayai operasinya dari sumber dana ini. Dana pihak ketiga (DPK) merupakan sumber dana yang dihimpun bank yang berasal dari masyarakat untuk menjalankan kegiatan operasinya. Menurut Siamat (2005:283), penggunaan dana bank sangat didominasi dalam bentuk penyaluran kredit. Terkonsentrasinya usaha bank dalam penyaluran kredit salah satunya karena sumber dana utama bank berasal dari dana masyarakat sehingga secara moral mereka harus menyalurkan kembali kepada masyarakat dalam bentuk kredit (Siamat, 2005:349). Dana dari masyarakat sangat penting bagi bank sebagai sumber dana yang digunakan untuk kegiatan operasi bank.

Kredit adalah penyediaan uang atau tagihan yang dapat dipersamakan dengan itu, berdasarkan persetujuan atau kesepakatan simpan pinjam meminjam antara bank dengan pihak lain yang mewajibkan pihak peminjam untuk melunasi hutangnya setelah jangka waktu tertentu dengan pemberian bunga (UU Perbankan No. 10 tahun 1998). Kredit adalah semua jenis pinjaman yang harus dibayar kembali bersama bunganya oleh peminjam sesuai dengan perjanjian yang telah disepakati (Hasibuan, 1996). Jenis-jenis kredit dibedakan berdasarkan sudut pendekatan yang berdasarkan tujuan kegunaannya, jangka waktu, macam, sektor perekonomian, agunan, golongan ekonomi, serta penarikan dan pelunasan (Hasibuan, 2011). Pertimbangan utama pemberian kredit adalah itikad baik (willingness to pay) dan kemampuan membayar (ability to pay) (Manurung, 2004). Prinsip kehati-hatian dalam pengelolaan bank serta adanya risiko yang selalu melekat dalam penyaluran dana, maka sebelum kredit atau pembiayaan disalurkan bank selalu ingin mengetahui segala sesuatu tentang kemampuan dan kemauan nasabah debiturnya untuk mengembalikan dana yang telah diberikan oleh bank (Susilo, 2000). Kebijaksanaan perkreditan bank harus diprogram dengan baik dan benar. Program perkreditan harus didasarkan pada asas yuridis, ekonomis dan kehati-hatian (Hasibuan, 2011): 1) Yuridis, artinya program perkreditan harus sesuai dengan undang-undang perbankan dan ketetapan bank Indonesia; 2) Ekonomis, artinya menetapkan rentabilitas yang ingin dicapai dan tingkat bunga kredit yang disalurkan; 3) Kehati-hatian, artinya besar plafon kredit (legal lending limit = BMPK) harus ditetapkan atas hasil analisis yang baik dan objektif berdasarkan asas 5C, 7P dan 3R dari setiap calon peminjam. 
Penelitian ini bertujuan untuk mengetahui dan menganalisis besarnya pengaruh PDRB, Inflasi, serta Dana pihak Ketiga baik secara langsung maupun tidak langsung terhadap Pertumbuhan Kredit di Bankaltim, sehingga kerangka konsep penelitian ini dapat digambarkan sebagai berikut:

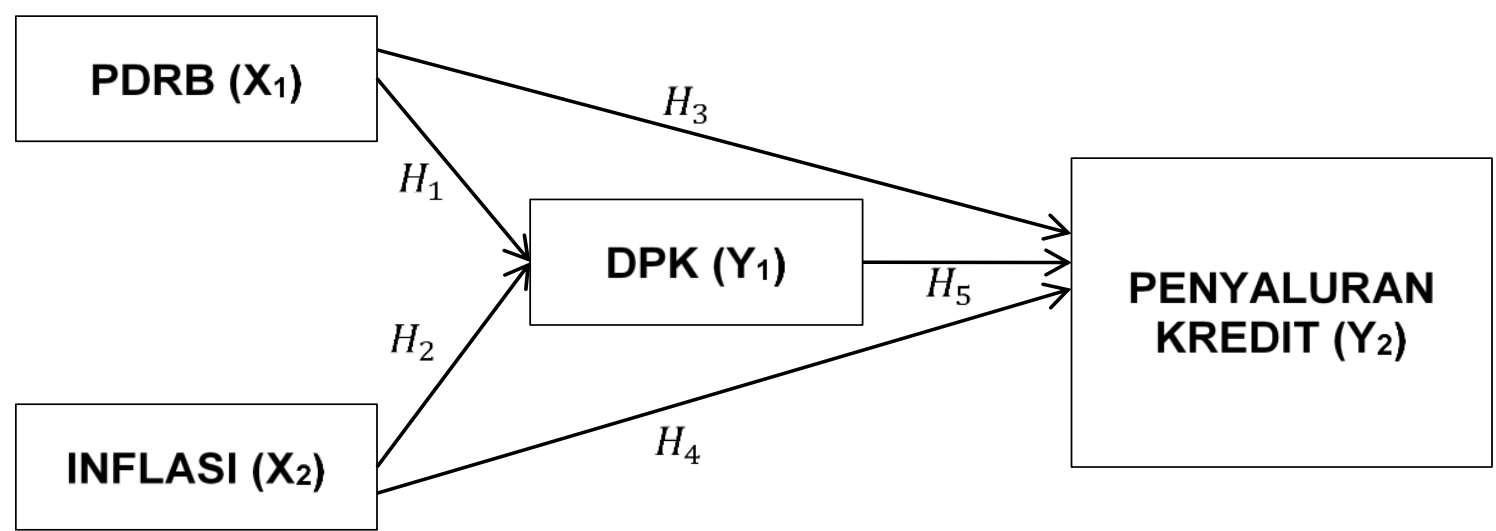

Gambar 1. Konsep Penelitian

Sumber: hasil olah data, 2016

Berdasarkan latar belakang serta perumusan masalah maka disusunlah hipotesis sebagai berikut:

1) Variabel Produk Domestik Regional Bruto (PDRB) berpengaruh langsung dan signifikan terhadap Dana Pihak Ketiga di Bankaltim;

2) Variabel Inflasi berpengaruh langsung dan signifikan terhadap Dana Pihak Ketiga di Bankaltim;

3) Variabel Produk Domestik Regional Bruto (PDRB) berpengaruh langsung dan signifikan terhadap Penyaluran Kredit Bankaltim;

4) Variabel Inflasi berpengaruh langsung dan signifikan terhadap Penyaluran Kredit Bankaltim;

5) Variabel Dana Pihak Ketiga berpengaruh langsung dan signifikan terhadap Penyaluran Kredit Bankaltim;

6) Variabel Produk Domestik Regional Bruto (PDRB) berpengaruh tidak langsung dan signifikan terhadap Penyaluran Kredit melalui Dana Pihak Ketiga di Bankaltim;

7) Variabel Inflasi berpengaruh tidak langsung dan signifikan terhadap Penyaluran Kredit melalui Dana Pihak Ketiga di Bankaltim.

\section{METODE}

Dalam penelitian ini, metode analisis data yang akan digunakan adalah analisis jalur (path analysis). Metode analisis jalur digunakan untuk menganalisis pola hubungan antar variabel. Tujuan analisis jalur adalah untuk mengetahui pengaruh langsung maupun tidak langsung melalui seperangkat variabel independen terhadap variabel dependen. Pengaruh dalam jalur tersebut ditunjukkan oleh koefisien jalur pada setiap diagram jalur dari hubungan kausal antar variabel bebas terhadap terikat (Riduwan, 2006:89). Pengaruh variabel intervening digunakan dalam metode analisis jalur (path analysis). Analisis jalur merupakan perluasan dari analisis regresi berganda, atau dengan kata lain analisis jalur adalah penggunaan analisis regresi untuk menaksir hubungan kausalitas antar variabel yang telah ditetapkan sebelumnya berdasarkan teori. Analisis jalur sendiri tidak dapat menentukan hubungan sebab akibat dan juga tidak dapat digunakan sebagai substitusi bagi peneliti untuk melihat hubungan kausalitas antar variabel. Hubungan kausalitas antar variabel telah dibentuk dengan model berdasarkan landasan teoretis, yang dilakukan oleh analisis jalur adalah menentukan pola hubungan antara tiga atau lebih variabel.

Hasil analisis deskripsi variabel yang dimasukkan model penelitian ini dapat dilihat dari tabel statistik deskriptif. Berdasarkan hasil olah data, dapat di deskripsikan sebagai berikut: 


\begin{tabular}{ccccc}
\hline \multicolumn{5}{c}{ Tabel 1. Deskriptif Data Penelitian } \\
\hline Tahun & $\begin{array}{c}\text { PDRB } \\
\text { per kapita } \\
\text { (Ribu Rp) }\end{array}$ & $\begin{array}{c}\text { Inflasi } \\
\mathbf{( \% )}\end{array}$ & $\begin{array}{c}\text { DPK } \\
\text { (Juta Rp) }\end{array}$ & $\begin{array}{c}\text { Kredit } \\
\text { (Juta Rp) }\end{array}$ \\
\hline 2006 & 69,8 & 6,4 & 10.992 .437 & 1.967 .785 \\
2007 & 95,1 & 8,3 & 11.513 .736 & 2.778 .724 \\
2008 & 83,1 & 13,06 & 13.229 .391 & 4.474 .585 \\
2009 & 90,6 & 4,31 & 10.549 .649 & 7.311 .523 \\
2010 & 105,8 & 7,28 & 11.608 .253 & 9.508 .892 \\
2011 & 121,2 & 6,35 & 19.254 .034 & 11.579 .490 \\
2012 & 124,5 & 5,6 & 26.165 .319 & 14.247 .534 \\
2013 & 124,6 & 9,65 & 21.048 .777 & 18.588 .373 \\
Min & 69,8 & 4,3 & 10.549 .649 & 1.967 .785 \\
Max & 124,6 & 13,1 & 26.165 .319 & 18.588 .373 \\
Mean & 101,8 & 7,6 & 15.545 .199 & 8.807 .113 \\
\hline
\end{tabular}

Sumber: hasil olah data, 2016

Tabel di atas menunjukkan bahwa PDRB per kapita terendah terjadi pada tahun 2006 sebesar 69,8 Ribu Rupiah, dan tertinggi terjadi pada tahun 2013 sebesar 124,6 Ribu Rupiah, dengan rata-rata PDRB per kapita di provinsi Kalimantan Timur adalah sebesar 101,8 Ribu Rupiah. Inflasi tertinggi di provinsi Kalimantan Timur terjadi pada tahun 2008 sebesar 13,06\%, dan terendah pada posisi 4,3\% di tahun 2009.

Tabel 5.1 juga menunjukkan bahwa Bankaltim mengalami fluktuasi Dana Pihak Ketiga dimana pada tahun 2009 Dana Pihak Ketiga adalah sebesar 10.549.649 Juta Rupiah menurun dari tahun sebelumnya sebesar 13.229.391 Juta Rupiah. Di Tahun 2012, Dana Pihak Ketiga di Bankaltim adalah terbesar yaitu 26.165.319 Juta Rupiah, walaupun pada tahun 2013 kembali mengalami penurunan menjadi 21.048.777 Juta Rupiah.

Permintaan Kredit di Bankaltim menunjukkan tendensi peningkatan dari tahun ke tahun, dengan permintaan kredit tertinggi ada di tahun 2013 sebesar 18.588.373 Juta Rupiah. Persamaan analisis jalur dalam penelitian ini adalah sebagai berikut:

\section{Persamaan sub-struktur pertama}

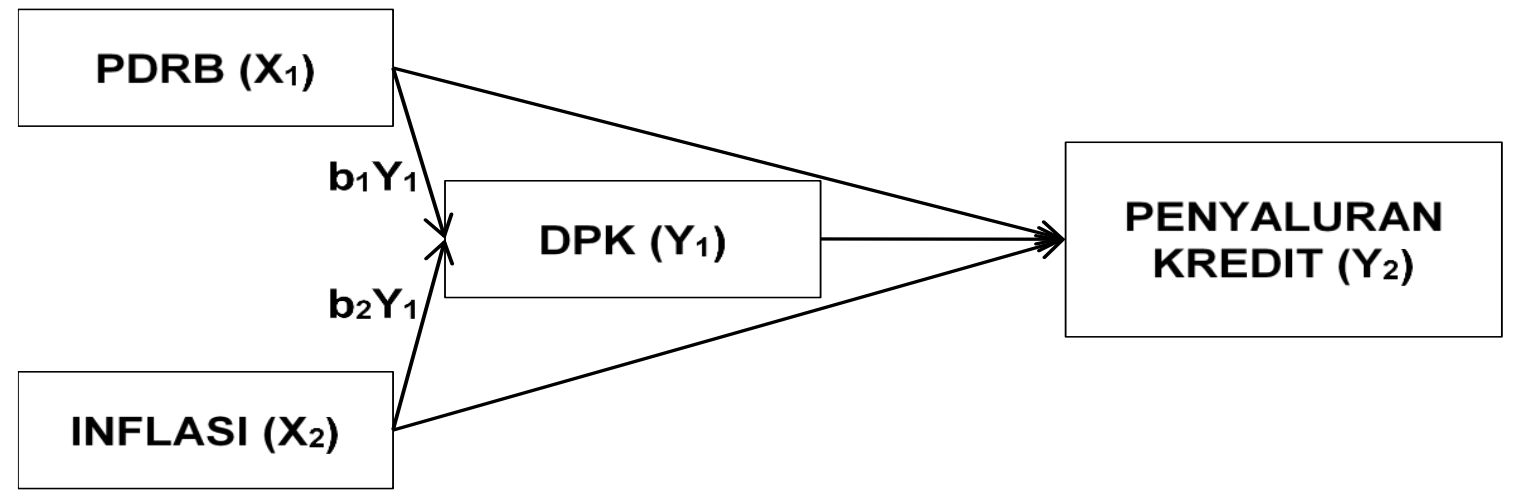

Gambar 2. Model Sub Struktur 1

Sumber: hasil olah data, 2016

$\mathrm{Y}_{1}=\mathrm{b}_{1} \mathrm{Y}_{1} \mathrm{X}_{1}+\mathrm{b}_{2} \mathrm{Y}_{1} \mathrm{X}_{2}+\mathrm{e}_{1}$

Keterangan:

$\mathrm{Y}_{1}=$ Dana Pihak Ketiga 


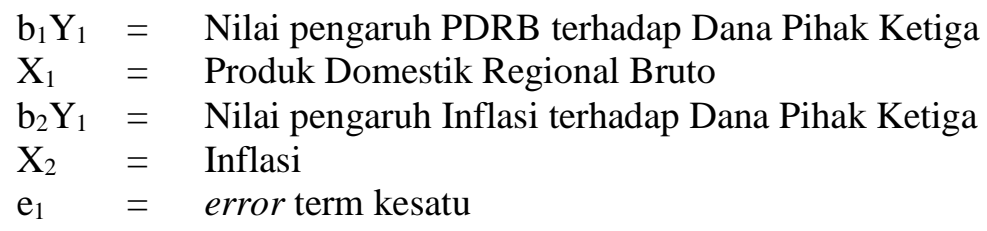

\section{Persamaan sub-struktur kedua}

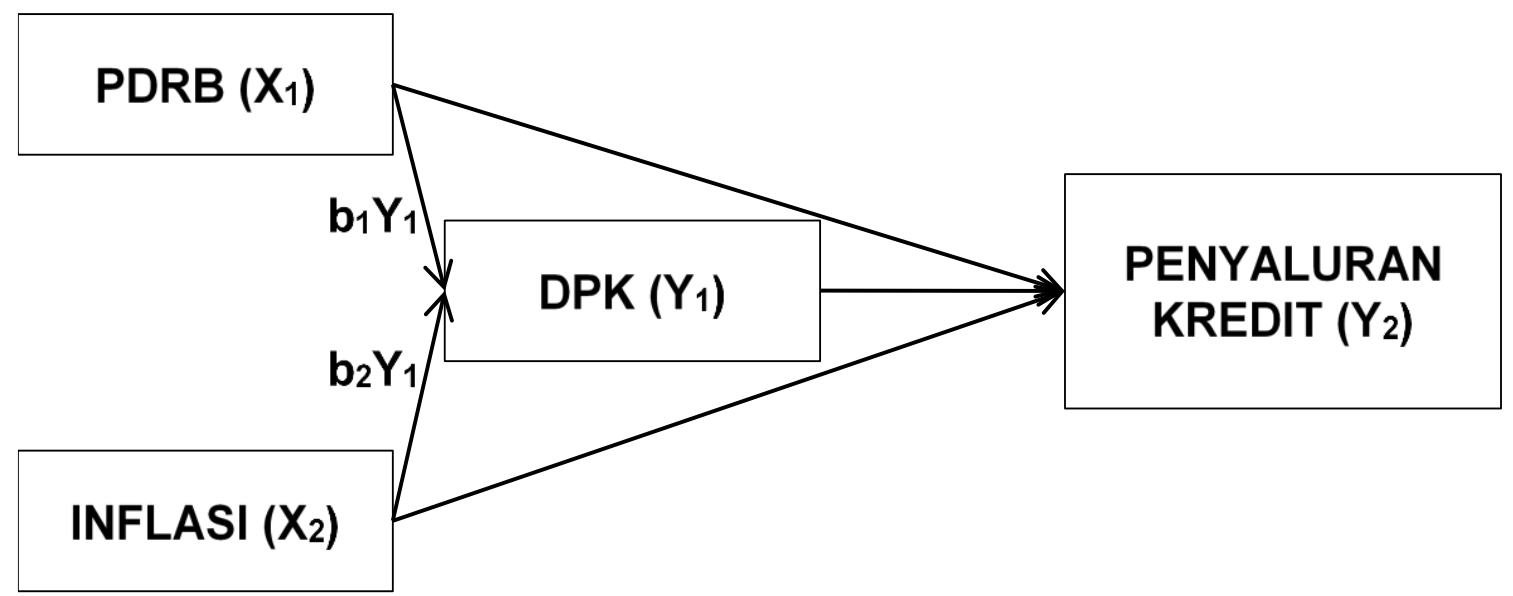

Gambar 3. Model Sub Struktur 2

Sumber: hasil olah data, 2016

$\mathrm{Y}_{2}=\mathrm{b}_{1} \mathrm{Y}_{2} \mathrm{X}_{1}+\mathrm{b}_{2} \mathrm{Y}_{2} \mathrm{X}_{2}+\mathrm{b}_{3} \mathrm{Y}_{2} \mathrm{Y}_{1}+\mathrm{e}_{1}$

Keterangan:

$\mathrm{Y}_{2}=$ Penyaluran Kredit

$\mathrm{b}_{1} \mathrm{Y}_{2}=$ Nilai pengaruh PDRB terhadap Penyaluran Kredit

$\mathrm{X}_{1}=\mathrm{PDRB}$

$\mathrm{b}_{2} \mathrm{Y}_{2}=$ Nilai pengaruh Inflasi terhadap Penyaluran Kredit

$\mathrm{X}_{2}=$ Inflasi

$\mathrm{b}_{3} \mathrm{Y}_{2}=$ Nilai pengaruh DPK terhadap Penyaluran Kredit

$\mathrm{Y}_{1}=$ Dana Pihak Ketiga

$\mathrm{e}_{2}=$ error term kedua

\section{HASIL DAN PEMBAHASAN}

Berdasarkan perhitungan dengan menggunakan model analisis jalur dan menggunakan bantuan program SPSS untuk mengolah data, maka diperoleh hasil sebagai berikut:

Model yang dibuat bebas dari gejala asumsi klasik. Data yang digunakan terdistribusi normal, bebas dari gejala multikolinearitas, tidak mengandung heteroskedastisitas dan tidak mengandung gejala otokorelasi, ini berarti bahwa hasil regresi pada analisis jalur dapat digunakan untuk memprediksi, sebagaimana yang dirangkum dalam tabel berikut:

Tabel 2. Kesimpulan Uji Asumsi Klasik Model

\begin{tabular}{lccc}
\hline \multicolumn{1}{c}{ Uji } & Syarat & Hasil & Interpretasi \\
\hline \multirow{2}{*}{ Normalitas 1 } & $\begin{array}{l}\text { Nilai Asymp.Sig } \\
(2 \text {-tailed })>0,05\end{array}$ & 0,2 & Terdistribusi normal \\
\cline { 2 - 4 } Normalitas 2 & $\begin{array}{l}\text { Nilai Asymp.Sig } \\
(2 \text {-tailed) }>0,05\end{array}$ & 0,2 & Terdistribusi normal \\
\hline
\end{tabular}




\begin{tabular}{|c|c|c|c|}
\hline Uji & Syarat & Hasil & Interpretasi \\
\hline \multirow[t]{2}{*}{ Multikolinieritas 1} & Nilai tollerance & $\begin{array}{c}\text { PDRB Tollerance }=0,98 \\
\text { VIF }=1,020\end{array}$ & $\begin{array}{l}\text { Bebas dari } \\
\text { multikolinieritas }\end{array}$ \\
\hline & $<1$ dan $\mathrm{VIF}<10$ & $\begin{array}{c}\text { Inflasi Tollerance }=0,98 \\
\text { VIF }=1,020\end{array}$ & $\begin{array}{l}\text { Bebas dari } \\
\text { multikolinieritas }\end{array}$ \\
\hline \multirow[t]{3}{*}{ Multikolinieritas 2} & & $\begin{array}{c}\text { PDRB Tollerance }=0,185, \\
\text { VIF }=3,185\end{array}$ & $\begin{array}{l}\text { Bebas dari } \\
\text { multikolinieritas }\end{array}$ \\
\hline & $\begin{array}{l}\text { Nilai tollerance } \\
<1 \text { dan } \text { VIF }<10\end{array}$ & $\begin{array}{c}\text { Inflasi Tollerance }=0,971, \\
\text { VIF }=1,030\end{array}$ & $\begin{array}{l}\text { Bebas dari } \\
\text { multikolinieritas }\end{array}$ \\
\hline & & $\begin{array}{c}\text { DPK Tollerance }=0,319 \\
\text { VIF }=3,133\end{array}$ & $\begin{array}{l}\text { Bebas dari } \\
\text { multikolinieritas }\end{array}$ \\
\hline Heteroskedastisitas 1 & Sign. $>0,05$ & 0,0575 & $\begin{array}{l}\text { Tidak mengandung } \\
\text { heteroskedastisitas }\end{array}$ \\
\hline Heteroskedastisitas 2 & Sign. $>0,05$ & 0,0505 & $\begin{array}{l}\text { Tidak mengandung } \\
\text { heteroskedastisitas }\end{array}$ \\
\hline Autokorelasi 1 & $\begin{array}{c}\text { Diantara } \mathrm{du}=1,62 \\
\text { dan } 4-\mathrm{du}=2,38\end{array}$ & Nilai DW = 2,031 & $\begin{array}{l}\text { Tidak mengandung } \\
\text { gejala otokorelasi }\end{array}$ \\
\hline Autokorelasi 2 & $\begin{array}{c}\text { Diantara } d u=1,62 \\
\text { dan } 4-d u=2,38\end{array}$ & Nilai DW = 1,892 & $\begin{array}{l}\text { Tidak mengandung } \\
\text { gejala autokorelasi }\end{array}$ \\
\hline
\end{tabular}

Sumber: hasil olah data, 2016

1. Pengujian Uji F dan Uji t secara komprehensif dan analisis regresi linear sederhana menunjukkan nilai yang positif pada semua jalur dengan hasil sebagai berikut:

Tabel 3. Koefisien Jalur

\begin{tabular}{cccc}
\hline Koefisien Jalur Model & Simbol & Nilai & Sig. \\
\hline Koefisien Jalur $\mathrm{X}_{1}$ Terhadap $\mathrm{Y}_{1}$ & $\rho \mathrm{y}_{1} \mathrm{x}_{1}$ & 0,831 & 0,023 \\
Koefisien Jalur $\mathrm{X}_{2}$ Terhadap $\mathrm{Y}_{1}$ & $\rho \mathrm{y}_{1} \mathrm{x}_{2}$ & 0,056 & 0,836 \\
Koefisien Jalur $\mathrm{X}_{1}$ Terhadap $\mathrm{Y}_{2}$ & $\rho \mathrm{y}_{2} \mathrm{x}_{1}$ & 0,761 & 0,107 \\
Koefisien Jalur $\mathrm{X}_{2}$ Terhadap $\mathrm{Y}_{2}$ & $\rho \mathrm{y}_{2} \mathrm{X}_{2}$ & 0,036 & 0,873 \\
Koefisien Jalur Y Terhadap Y & $\rho \mathrm{y}_{1} \mathrm{y}_{2}$ & 0,181 & 0,645 \\
Koefisien Jalur X $\mathrm{X}_{1}$ Terhadap Y Melalui $\mathrm{Y}_{1}$ & $\rho \mathrm{x}_{1} \mathrm{y}_{1} \mathrm{y}_{2}$ & 0,150 & \\
Koefisien Jalur $\mathrm{X}_{2}$ Terhadap $\mathrm{Y}_{2}$ melalui $\mathrm{Y}_{1}$ & $\rho \mathrm{x}_{2} \mathrm{y}_{1} \mathrm{y}_{2}$ & 0,010 & \\
\hline
\end{tabular}

Sumber: hasil olah data, 2016

2. Besar pengaruh dari hubungan langsung maupun langsung dan total pengaruh masing-masing variabel dapat dilihat pada tabel berikut:

Tabel 4. Pengaruh Langsung dan Tidak Langsung

\begin{tabular}{|c|c|c|c|}
\hline & Langsung & Tidak Langsung & Total Pengaruh \\
\hline Koefisien Jalur $\mathrm{X}_{1}$ Terhadap $\mathrm{Y}_{1}$ & 0,831 & & 0,831 \\
\hline Koefisien Jalur $\mathrm{X}_{2}$ Terhadap $\mathrm{Y}_{1}$ & 0,056 & & 0,056 \\
\hline
\end{tabular}




\begin{tabular}{cccc}
\hline \hline & Langsung & Tidak Langsung & Total Pengaruh \\
\hline Koefisien Jalur $\mathrm{X}_{1}$ Terhadap $\mathrm{Y}_{2}$ & 0,761 & & 0,761 \\
Koefisien Jalur $\mathrm{X}_{2}$ Terhadap $\mathrm{Y}_{2}$ & 0,036 & & 0,036 \\
Koefisien Jalur $\mathrm{Y}_{1}$ Terhadap $\mathrm{Y}_{2}$ & 0,181 & & 0,181 \\
Koefisien Jalur $\mathrm{X}_{1}$ Terhadap $\mathrm{Y}_{2}$ Melalui $\mathrm{Y}_{1}$ & & 0,150 & 0.911 \\
Koefisien Jalur $\mathrm{X}_{2}$ Terhadap $\mathrm{Y}_{2}$ melalui $\mathrm{Y}_{1}$ & & 0,010 & 0.046 \\
\hline
\end{tabular}

Sumber: hasil olah data, 2016

Untuk memperjelas hasil penelitian melalui path analysis dapat dilihat gambar berikut ini:

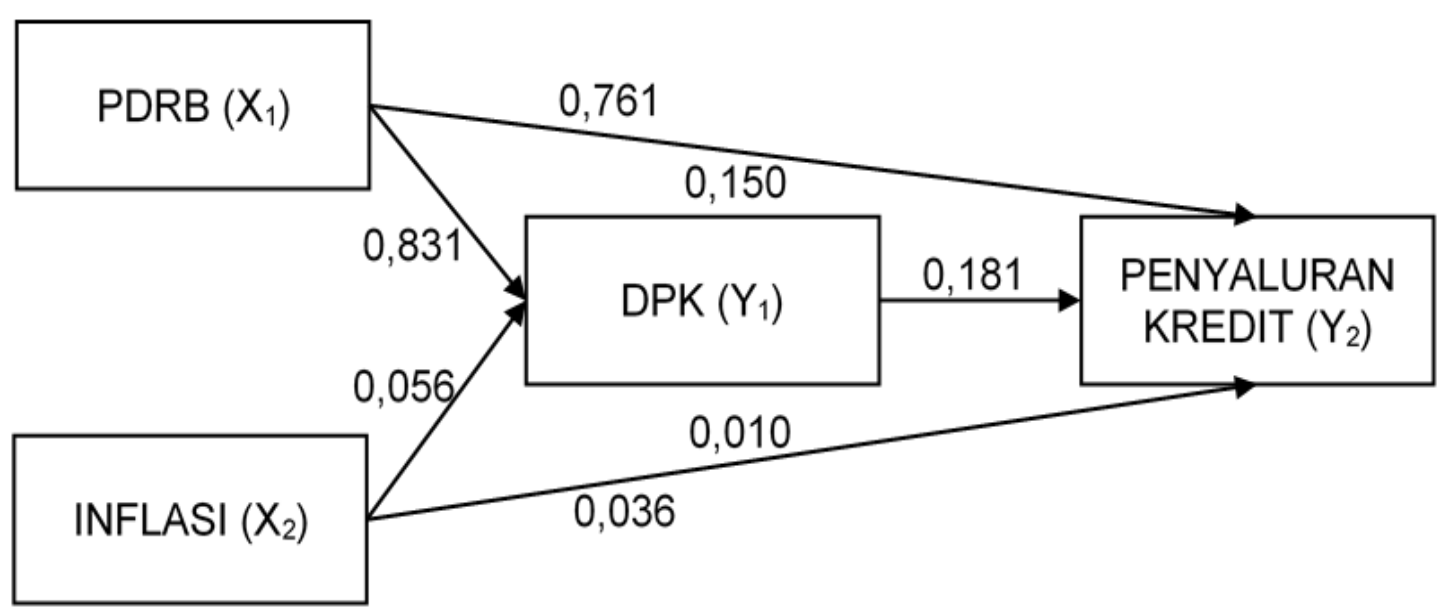

Gambar 4. Besar Pengaruh Langsung dan Tidak Langsung

Sumber: hasil olah data, 2016

3. Setelah melihat analisis jalur melalui koefisien jalur dan koefisien determinasi, maka selanjutnya akan dilakukan pengujian hipotesis yang telah diajukan. Hasil pengujian hipotesis untuk menjawab hipotesis yang telah diajukan menunjukkan bahwa:

a. Variabel PDRB berdasarkan hasil nilai t hitung sebesar 3,257 dengan nilai P-value PDRB sebesar 0,023 < 0,05 sehingga H0 ditolak dan H1 diterima, hal ini menunjukkan bahwa PDRB berpengaruh signifikan terhadap DPK.

b. Variabel Inflasi berdasarkan hasil nilai t hitung sebesar 0,219 dengan nilai P-value Inflasi sebesar 0,836 > 0,05 sehingga $\mathrm{H} 0$ diterima dan $\mathrm{H} 2$ ditolak, hal ini menunjukkan bahwa Inflasi tidak berpengaruh signifikan terhadap DPK.

c. Variabel PDRB berdasarkan hasil nilai t hitung sebesar 2,074 dengan nilai P-value PDRB sebesar 0,107>0,05 sehingga $\mathrm{H} 0$ diterima dan H3 ditolak, hal ini menunjukkan bahwa PDRB tidak berpengaruh signifikan terhadap Penyaluran kredit.

d. Variabel Inflasi berdasarkan hasil nilai t hitung sebesar 0,170 dengan nilai P-value Inflasi sebesar 0,873>0,05 sehingga $\mathrm{H} 0$ diterima dan $\mathrm{H} 4$ ditolak, hal ini menunjukkan bahwa Inflasi tidak berpengaruh signifikan terhadap Penyaluran kredit.

e. Variabel DPK berdasarkan hasil nilai t hitung sebesar 0,497 dengan nilai P-value DPK sebesar 0,645 > 0,05 sehingga H0 diterima dan H5 ditolak, hal ini menunjukkan bahwa DPK tidak berpengaruh signifikan terhadap Penyaluran kredit.

f. Variabel PDRB melalui DPK berdasarkan hasil sebesar 0,150 sehingga H0 diterima dan H6 ditolak, hal ini menunjukkan bahwa PDRB melalui DPK tidak berpengaruh signifikan terhadap Penyaluran kredit. 
g. Variabel Inflasi melalui DPK berdasarkan hasil sebesar 0,010 sehingga H0 diterima dan H7 ditolak, hal ini menunjukkan bahwa Inflasi melalui DPK tidak berpengaruh signifikan terhadap Penyaluran kredit.

\section{SIMPULAN}

Kesimpulan yang dapat diberikan penelitian ini adalah sebagai berikut:

1. PDRB berpengaruh positif dan signifikan terhadap DPK. Peningkatan PDRB mencerminkan bahwa perekonomian daerah dan perekonomian rakyat yang semakin baik meningkatkan kepercayaan untuk melakukan penyimpanan dana dalam bentuk giro, tabungan, ataupun deposito.

2. Inflasi berpengaruh positif namun tidak signifikan terhadap DPK. Kondisi ini mencerminkan bahwa ketika Inflasi tinggi, jumlah Dana Pihak Ketiga yang dihimpun justru ikut meningkat karena suku bunga simpanan juga akan ditingkatkan oleh bank guna menjaga likuiditasnya sehingga menyebabkan masyarakat enggan untuk menarik simpanannya.

3. PDRB berpengaruh positif namun tidak signifikan terhadap penyaluran kredit. Hasil ini menunjukkan dengan adanya kenaikan PDRB maka tingkat konsumsi masyarakat akan semakin meningkat, oleh sebab itu jika PDRB meningkat maka permintaan akan kredit juga akan mengalami peningkatan guna mencukupi tingkat konsumsi yang dihadapi oleh masyarakat.

4. Inflasi berpengaruh positif namun tidak signifikan terhadap penyaluran kredit. Ketika inflasi tinggi maka daya beli masyarakat menjadi rendah berbanding terbalik dengan kebutuhan sehingga masyarakat akan mengajukan kredit kepada Bankaltim untuk memenuhi kebutuhan sehari-harinya tersebut sebagai bentuk adanya ekspektasi bahwa inflasi akan kembali turun dan nilai uang lebih rendah dibandingkan pada saat meminjam dan ini akan memberikan keuntungan kepada nasabah.

5. DPK berpengaruh positif namun tidak signifikan terhadap penyaluran kredit. Penyaluran kredit tidak dipengaruhi oleh jumlah DPK yang dihimpun karena adanya dana-dana lainnya yang bisa disalurkan selain Dana Pihak Ketiga yang dihimpunnya dari masyarakat serta semakin tingginya tingkat persaingan Lembaga Keuangan baik Bank maupun non Bank mempersulit dalam penyaluran kredit.

6. PDRB berpengaruh positif terhadap penyaluran kredit melalui DPK. Peningkatan PDRB berdampak kepada peningkatan taraf pendapatan masyarakat dan meningkatkan penyaluran kredit karena iklim ekonomi yang positif memacu masyarakat untuk melakukan pinjaman dengan berbagai tujuan.

7. Inflasi berpengaruh positif terhadap penyaluran kredit melalui DPK. Inflasi yang meningkat akan menyebabkan suku bunga simpanan juga akan ditingkatkan oleh bank guna menjaga likuiditasnya dan berdampak masyarakat enggan untuk menarik simpanannya karena masyarakat akan memperoleh pendapatan bunga yang lebih tinggi.

\section{DAFTAR PUSTAKA}

Affandy, Muhammad. (2011). Pengaruh PDRB Riil dan Tingkat Suku Bunga Terhadap Tabungan Masyarakat di Propinsi Sulawesi Selatan periode 1995-2009. Skripsi. Jurusan Ilmu Ekonomi Fakultas Ekonomi dan Bisnis Universitas Hasanuddin, Makassar.

Anthony, Orji. (2012). Bank Savings and Bank Credit in Nigeria: Determinants and Impact on Economics Growth. International Journal of Economics and Financial Issues. Vol.2 No.3. pp.357372.

Bank Indonesia. (2014). Moneter. www.bi.go.id/id/moneter/inflasi. Diakses 17 Desember 2015.

Chaturvedi, Vaibhav., Brajesh Kumar dan Ravindra H. Dholakia. (2009). Inter-relationship Between Economic Growth, Savings and Inflation in Asia. Journal Of International Economics Studies. Vol.- No.23. pp. 1-22.

Hasibuan, Malayu S. P. (1996). Manajemen Perbankan Dasar dan Kunci Keberhasilan Perekonomian. Jakarta: Toko Gunung Agung. 
Hendra, Yenny. (2012). Analisis Pengaruh PDRB, Suku Bunga, Tingkat Inflasi dan Kurs Valuta Asing terhadap Simpanan masyarakat pada Bank Umum di Kalimantan Barat. Tesis Program Magister Ilmu Ekonomi. Universitas Tanjungpura, Pontianak.

Hossain, Akhtar. (2010). The Evolution of Central Banking and Monetary Policy in the Asia-Pacific. USA: Edward Elgar Publishing.

Kasmir. (2004). Bank dan Lembaga Keuangan Lainnya. Jakarta: PT. Raja Grafindo Persada.

Manurung, Mandala, dan Prathama Rahardja. (2004). Uang, Perbankan, Dan Ekonomi Moneter: Kajian Kontekstual Indonesia: Berdasarkan UU No. 7/1992 Sebagaimana Diubah Dengan UU No. 10/1998, UU No. 3/2004 (Perubahan Atas UU No. 23/1999): Dilengkapi Arsitektur Perbankan Indonesia (API). Penerbitan Fakultas Ekonomi Universitas Indonesia, Jakarta.

Mishkin, Frederic S. (2008). Ekonomi Uang, Perbankan, dan Pasar Keuangan. Edisi Sembilan, jilid 2. Jakarta: Penerbit Salemba Empat.

Republik Indonesia. (1998). Undang-Undang Nomor Nomor 10 Tahun 1998 Tentang Perubahan Atas UU No. 7 Tahun 1992 Tentang Perbankan.

Riduwan. (2006). Metode dan Teknik Menyusun Tesis, Cetakan 4. Bandung: Alfabeta.

Siamat, Dahlan. (2005). Manajemen Lembaga Keuangan: "Kebijakan Moneter dan Perbankan". Fakultas Ekonomi Universitas Indonesia, Jakarta.

Sukirno, Sadono. (2006). Ekonomi Pembangunan Proses masalah dan Dasar Kebijakan, cetakan ketiga. Jakarta: Penerbit Kencana.

Sultana, Samar and Anwar Ali Shah G. Syed. (2010). Macroeconomic Determinants of Savings and Investment in Pakistan. Journal of Business Strategies. Vol. 4 No. 2. pp. 28-42.

Susilo, Sri Y. (2000). Bank dan Lembaga Keuangan Lain. Jakarta: Salemba Empat. 